\title{
Building the Data Mart on Antibiotic Usage for Infection Control
}

\author{
Insoo Rheem \\ Department of Laboratory Medicine, Dankook University Hospital, Cheonan 31116, Korea
}

\section{감염관리를 위한 항생제 사용량 데이터마트의 구축}

\author{
임인수 \\ 단국대학교병원 진단검사의학과
}

\begin{abstract}
Data stored in hospital information systems has a great potential to improve adequacy assessment and quality management. Moreover, an establishment of a data warehouse has been known to improve quality management and to offer help to clinicians. This study constructed a data mart that can be used to analyze antibiotic usage as a part of systematic and effective data analysis of infection control information. Metadata was designed by using the XML DTD method after selecting components and evaluation measures for infection control. OLAP-a multidimensional analysis tool-for antibiotic usage analysis was developed by building a data mart through modeling. Experimental data were obtained from data on antibiotic usage at a university hospital in Cheonan area for one month in July of 1997 . The major components of infection control metadata were antibiotic resistance information, antibiotic usage information, infection information, laboratory test information, patient information, and infection related costs. Among them, a data mart was constructed by designing a database to apply antibiotic usage information to a star schema. In addition, OLAP was demonstrated by calculating the statistics of antibiotic usage for one month. This study reports the development of a data mart on antibiotic usage for infection control through the implementation of XML and OLAP techniques. Building a conceptual, structured data mart would allow for a rapid delivery and diverse analysis of infection control information.
\end{abstract}

Key words: Infection control, Data mart, Data warehouse, Antibiotic

This is an Open Access article distributed under the terms of the Creative Commons Attribution Non-Commercial License (http://creativecommons.org/licenses/by-nc/4.0) which permits unrestricted non-commercial use, distribution, and reproduction in any medium, provided the original work is properly cited.

Copyright @ 2016 The Korean Society for Clinical Laboratory Science. All rights reserved.
Corresponding author: Insoo Rheem Department of Laboratory Medicine, Dankook University Hospital, 201 Manghyang-ro, Dongnam-gu, Cheonan 31116, Korea Tel: 82-41-550-6668 Fax: 82-41-550-7055

E-mail: insoo@dankook.ac.kr

Received: October 11, 2016 Revised: October 25, 2016 Accepted: October 25, 2016

\section{서 론}

항생제의 개발로 감염질환 치료의 획기적인 전기를 맞게 되었으 나 항생제의 과용 및 남용으로 항생제 내성 균주들이 점차 증가하 게 되었고, 효과적인 감염관리를 위하여 각 의료기관에서는 항생제 감수성 통계와 더불어 항생제 사용 양태의 분석이 필요하게 되었다 [1-3]. 이에 연구자는 일개 대학병원의 항생제 사용 경향을 분석하 고 결과를 보고한 바 있었다[4]. 이러한 경험을 통해 느꼈던 것은 많 은 노력이 들어감에도 불구하고 일회성 결과일 수밖에 없는 한계이
었다. 본 연구는 이러한 제한점을 극복하고자 지속적인 활용과 빠 른 응답이 가능한 감염관리 데이터마트를 고안하였고 다차원 데이 터 분석이 가능한 온라인 분석처리(online analytical processing, OLAP)의 적용을 통해서 체계적이고 다양한 항생제 사용량 분석을 시현하고자 하였다.

감염관리의 주요 구성 요소들과 유용한 평가 척도는 미국 질병 통제센터(CDC) 지침, 대한병원감염관리학회에서 권장하는 내용, 단국대학교병원의 감염 관리 지침 및 관련 문헌들을 검토하여 설계 하였다[5-8]. 감염관리에 필요한 주요 구성요소는 항생제 내성, 항 
생제 사용량, 병원 감염, 감염 관련 비용으로 산정하여 감염관리 메 타데이터 설계에 적용하였다.

일반적인 데이터베이스가 사건처리 중심으로 데이터를 수립하 는데 비하여, 데이터웨어하우스 및 데이터마트는 정보의 분석을 손 쉽게 할 수 있도록 일정한 주기로 유용한 데이터들이 통합되고 요 약된 데이터 모임을 말하며 정보의 본질이 재정의된다고 할 수 있 다. 이와 같이 데이터웨어하우스는 의사결정에 필요한 데이터 처리 기능을 효율적으로 지원하기 위한, 양질의 데이터베이스이다 $[9,10]$.

데이터마트는 기관 전체가 아니라 해당 부서 또는 특정 분야에 관련된 모든 데이터를 포함한다. 예를 들어 사용자들은 병원 전체 가 아닌 특정 부서에 관한 데이터에 쉽게 접근이 가능하다. 이러한 사실 때문에 데이터마트는 데이터웨어하우스에 비해 짧은 개발 기 간 및 저렴한 개발 비용, 그리고 용이한 데이터 유지보수와 같은 장 점을 가지고 있다.

\section{재료 및 방법}

\section{1. 연구 설계}

데이터마트의 구축은 감염관리의 구성 요소 및 평가 척도를 선 정 후 다목적 마크업 언어(extensible markup language, $\mathrm{XML}$ )와 문서 형식 정의(document type definition, DTD)를 이용하여 메 타데이터 및 데이터베이스를 설계하였다. OLAP 구현은 항생제 사 용량 데이터베이스에 대한 모델링을 실시하여 데이터마트를 실험 구축하는 순서로 하였다.

\section{2. 연구 대상}

데이터마트 및 OLAP 구현을 위한 실험 자료는 1997년 7월 한 달 동안의 천안 지역의 일개 대학병원의 항생제 사용량 자료 및 항
생제 사용량의 목적에 대한 조사 자료를 이용하였다.

\section{3. 연구 도구}

데이터베이스 도구는 관계형 데이터베이스 시스템(relational database management system)인 Microsoft SQL 2000 (Microsoft, Redmond, WA, USA)을 사용하였다. XML 도구는 Tagfree XML Editor, Tagfree DTD Editor (Dasan Technology, Pusan, Korea)를 사용하였다. 자료 분석을 위한 질의 도구는 MS $\mathrm{SQL}$ 에 포함되어 있는 다차원 분석 도구인 OLAP을 이용하였다.

\section{4. 감염관리 메타데이터 설계 및 주요 감염관리 평가 척도 선정}

항생제 감수성 자료, 항생제 사용량, 진단, 치료방법, 처치(수술), 환자 분포 정보, 감염관리조사 결과가 메타데이터 구축을 위한 구 성요소가 되며, 이들 요소로부터 원하는 평가 요소에 적합한 평가 척도를 선정하였다.

\section{5. 감염관리 데이터마트(OLAP) 설계}

관계형 데이터베이스는 개체 관계도(entity-relationship diagram, ERD)를 사용하여 감염관리 메타데이터 설계를 하였다. 이들 구성 요소를 기반으로 항생제 사용량 분석에 대한 데이터마트 를 스타 스키마 모델링을 이용하여 설계하였다.

\section{결 과}

\section{1. 감염관리 메타데이터 설계}

항생제 사용량의 평가는 병동 별, 과 별, 종류 별로 구분할 수 있 으며 평가 척도로는 일일상용량(defined daily dose, DDD), 치료 일수, 치료기간, 병합사용일수가 있다. 항생제 사용량, 항생제 내 성, 병원감염 정보에 대한 관련 구성 요소는 Table 1과 같다. 환자

Table 1. Measures and variables of data mart on antibiotic usage

\begin{tabular}{|c|c|c|}
\hline 항생제 사용량 & 항생제 내성 & 병원감염 \\
\hline $\begin{array}{l}\text { 약제(항생제) 처방 정보 } \\
\text { 환자 정보 } \\
\text { 환자 기본정보 } \\
\text { 환자 이력정보 } \\
\text { 환자 병력정보: 진단, 처치, 퇴원요약 } \\
\text { 항생제 정보 } \\
\text { 항생제 기본정보: 코드, 일반명, 용량, 용법 } \\
\text { 항생제 특성정보: 종류, 적응증 } \\
\text { ATC/DDD }\end{array}$ & $\begin{array}{l}\text { 미생물 검사 결과 정보 } \\
\text { 검체(환자) 정보: 처방/채취/접수 } \\
\text { 감수성 항생제 이력 정보 } \\
\text { 검체 종류 정보 } \\
\text { 균명 정보 } \\
\text { 항생제 검사 관련 정보 } \\
\text { 종류(MIC, Disk, E-test) } \\
\text { 차수(1차, 2차) } \\
\text { 감수성 판정 기준 }\end{array}$ & $\begin{array}{l}\text { 환자 기본 정보 } \\
\text { 검체 정보 } \\
\text { 감염 관련 정보: 감염일, 부위, 경과 } \\
\text { 항생제 사용관련: 종류, 사용량 } \\
\text { 미생물 검사결과: 검체, 균명, 감수성 } \\
\text { 감염위험요소 } \\
\text { IV Catheter } \\
\text { Hyperalimentation } \\
\text { A-line } \\
\text { Foley catheter } \\
\text { Intubation } \\
\text { Tracheostomy } \\
\text { CNS shunt } \\
\text { 특수검사 및 처치 }\end{array}$ \\
\hline
\end{tabular}


정보는 등록번호, 입원일, 퇴원일, 입원실 변경 이력, 생년월일, 성 별, 진단명, 수술명, 수술일, 퇴원 요약 정보로 구성하였다. 감염 관 련 비용과 관련된 구성요소는 검사비, 약제비, 처치료, 병실료, 진 단명, 수술명, 감염 관련 추가 재원일수, 감염 관련 추가 진료비용으 로 열거되었다.

\section{2. 문서 형식 정의(DTD) 설계}

감염관리 데이터마트의 XML DTD 상위 요소는 항생제 내성 정 보, 항생제 사용량 정보, 감염 정보, 검사 정보로 구성하였다.

1) 항생제 내성 정보의 개체 관계도

항생제 내성 정보의 개체 관계도는 Fig. 1과 같다.

2) 항생제 사용량 정보의 개체 관계도

항생제 사용량 정보의 개체 관계도는 Fig. 2와 같다.

3) 항생제 사용량 정보의 문서형식정의

항생제 사용량 정보의 문서 형식 정의(DTD)는 Fig. 3 와 같다.

4) 스타 스키마 모델 적용을 위한 항생제 사용량 정보의 개체 관계도 항생제 사용량 정보를 스타 스키마에 적용하기 위한 데이터베이 스의 설계는 Fig. 4 와 같다.
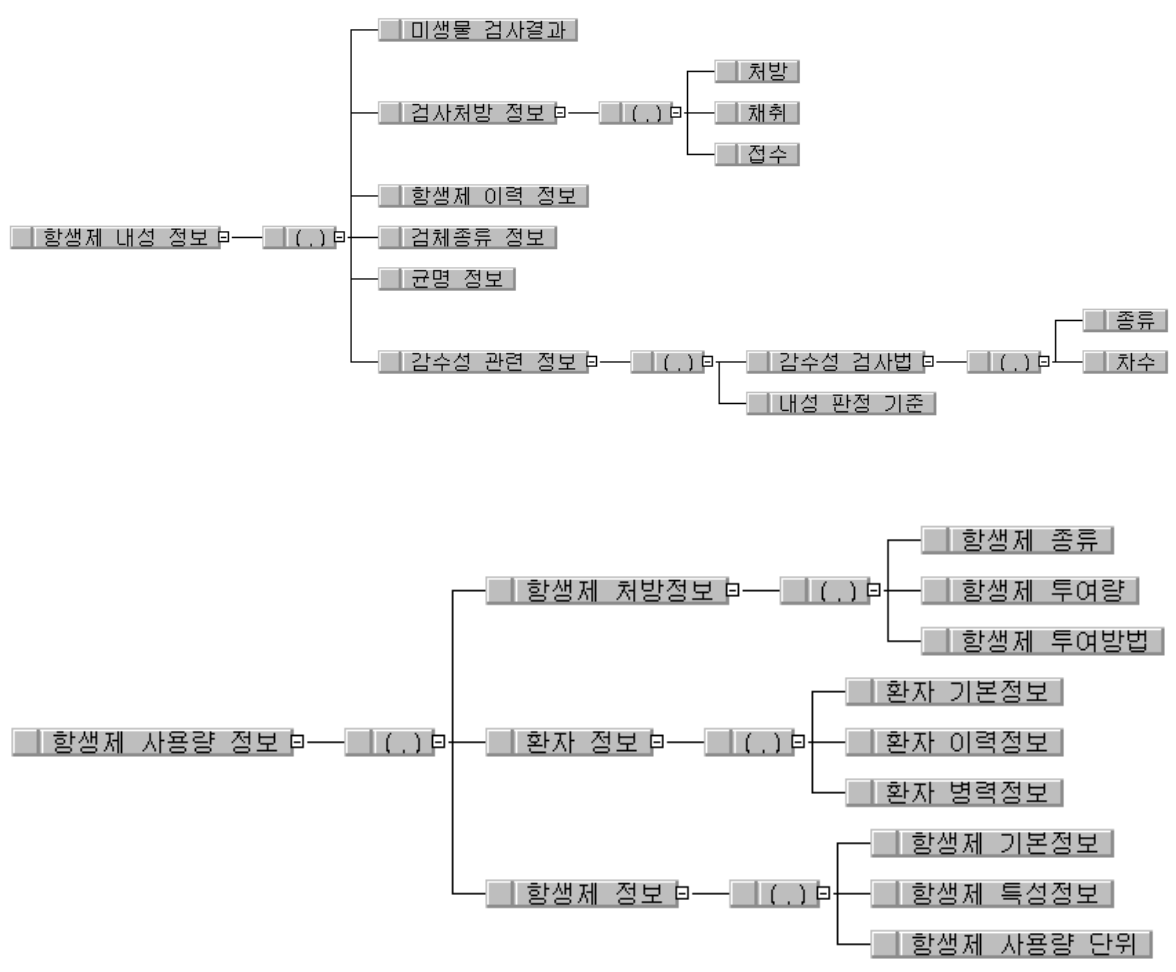

\section{OLAP 모델링}

1) 항생제 사용량 큐브의 구조

스타 스키마는 처리의 중심이 되는 사실 테이블과 시간 데이터 를 포함하는 차원 테이블들로 구성된다. 항생제 사용량 분석을 위 한 큐브는 다음과 같은 스타 스키마 구조로 설계하였다(Fig. 5).

2) 항생제 사용량 사실 테이블의 스타 스키마

항생제 사용량 스타 스키마는 Fig. 6과 같이 설계되었다.

3) 항생제 사용량 OLAP에서 큐브 탐색의 예

1997년 7월 한 달 동안의 항생제 사용량 자료에 대한 OLAP를 구현하였고 Microsoft SQL 2000의 큐브 브라우저를 이용하여 자 료를 탐색하였다.

Fig. 7은 한 달 동안 일반외과 수술이 시행된 남자 환자에서 비경 구로 투여된 항생제 사용량을 종류별로 산출한 예이다. 투여목적 (Use)에 따른 항생제 종류별로 항생제 사용일수를 집계하였다. 세 팔로스포린 계열 항생제의 경우 예방적 대 치료적 사용의 비 (prophylactic vs. therapeutic ratio)는 3.9: 1 (4,245일 : 1,089 일)이었다(Fig. 8).
Fig. 1. Entity-relationship diagram (ERD) of information on antibiotic resistance.

Fig. 2. Entity-relationship diagram (ERD) of information on antibiotic utilization. 


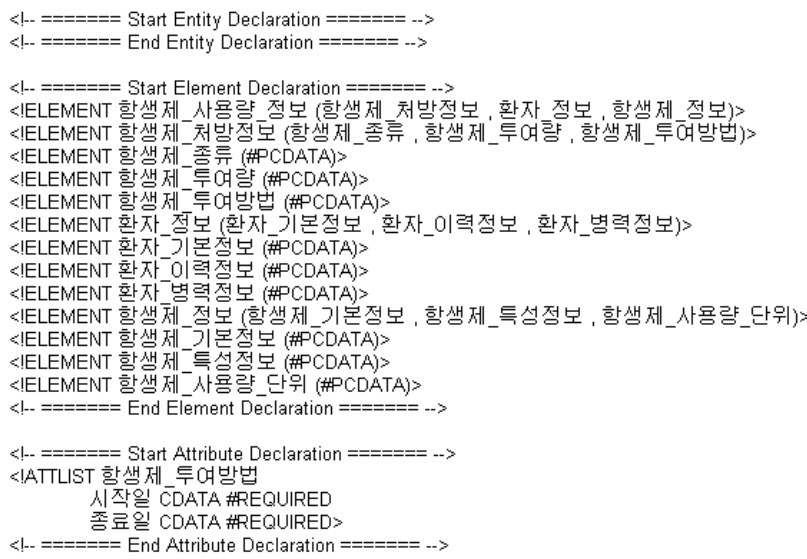

Fig. 3. Document type definition (DTD) for antibiotic utilization.

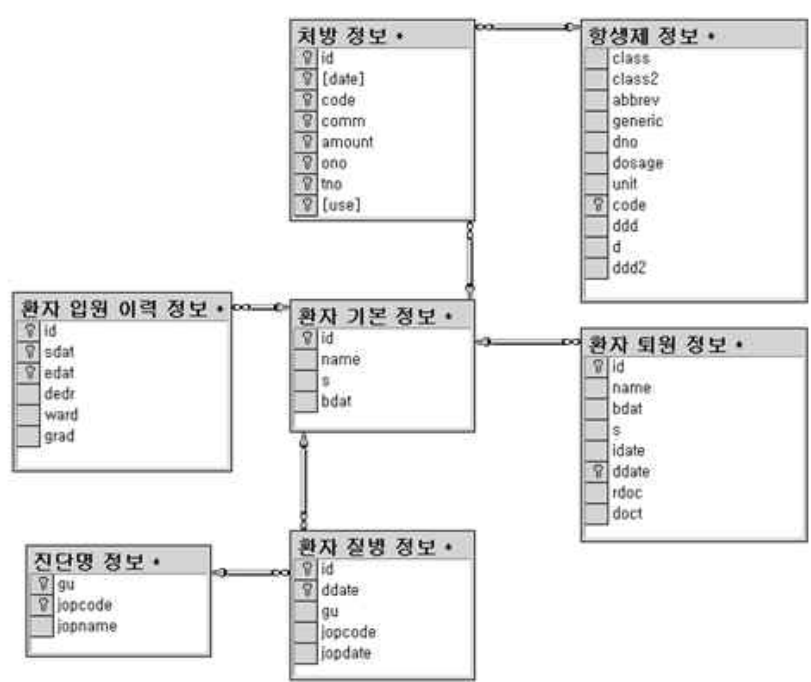

Fig. 4. Entity-relationship diagram (ERD) for antibiotic usage database.

\section{고 찰}

병원의 질 향상 평가의 여러 기준 중 항생제의 사용은 중요한 지 표로서 미국에서는 지속적인 연구가 보고되고 있다[11,12]. 국내 에서도 감염관리와 항생제 사용의 평가 및 제한 항생제 사용의 결 과 등에 대한 보고가 있고[13-16], 병원의 질 향상에 관한 정부 및 각 병원 단체들의 관심이 증가하고 있으며 항생제의 올바른 사용에 관한 보고가 있었다[3,17,18]. 국내 현실에 맞는 항생제의 적절한 사용을 위한 전략적 목표와 지표를 마련하기 위하여 국내 항생제 사용의 현황을 파악하는 것이 중요하다. 본 연구는 이러한 시의에 부응하여 감염관리의 질 향상을 위한 방법론적 접근을 시도하고자 하였다.

\section{항생제 사용 Cube}

환자 정보 차원: 등록번호/성별/연령/과

항생제 사용방법 차원: 투여 경로/사용 목적

항생제 사용량 차원: 사용량(DDD)

항생제 사용일수 차원: 사용일수(IDD)/사용기간

항생제 정보 차원: 코드/일반명/항생제 계열

환자 정보 차원: 등록번호/성별/연령/과

Fig. 5. Cube structure of antibiotic usage database.

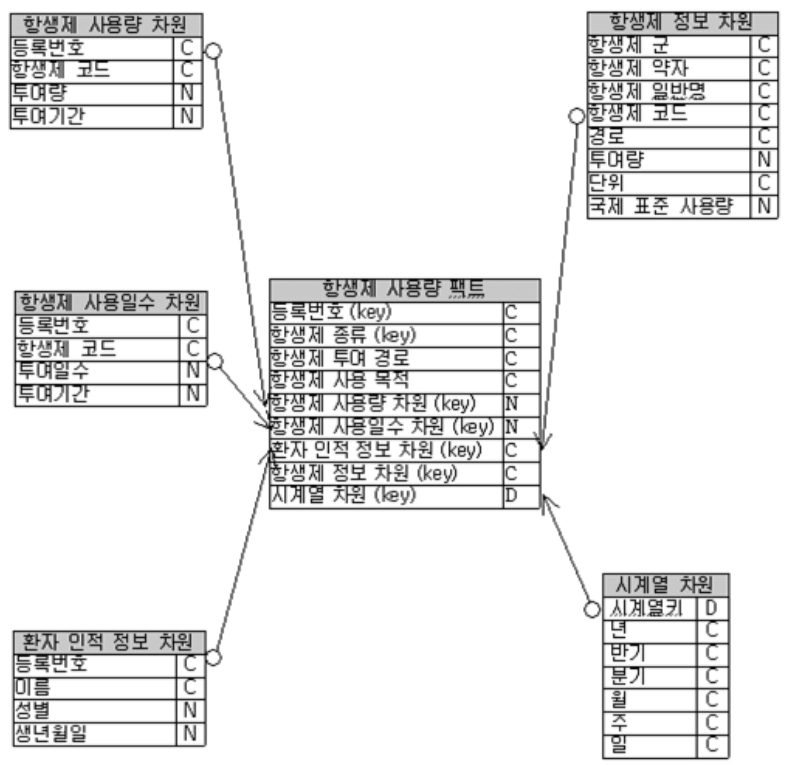

Fig. 6. Entity-relationship diagram (ERD) for star schema of antibiotic usage.

2003년 Wisniewski 등은 1998년부터 5개년 계획으로 진행된 Chicago Antimicrobial Resistance Project (CARP) 구축을 보고 하였다[5]. CARP는 항생제 내성 관리를 목적으로 하여 병원감염, 항생제 내성, 항생제 사용량 및 비용 활용의 분석을 포함하는 본격 적인 감염관리를 위한 데이터웨어하우스라고 볼 수 있다. 2000년 대 전후로 고객 관계 관리(Customer relationship management, $\mathrm{CRM}$ ) 시스템 구축을 위한 방안으로 데이터웨어하우스가 기업에 활발하게 도입되었는데, 이것은 컴퓨터와 정보통신기술의 발전과 고객관계를 공동창조의 파트너로 보는 비즈니스 패러다임의 변화 


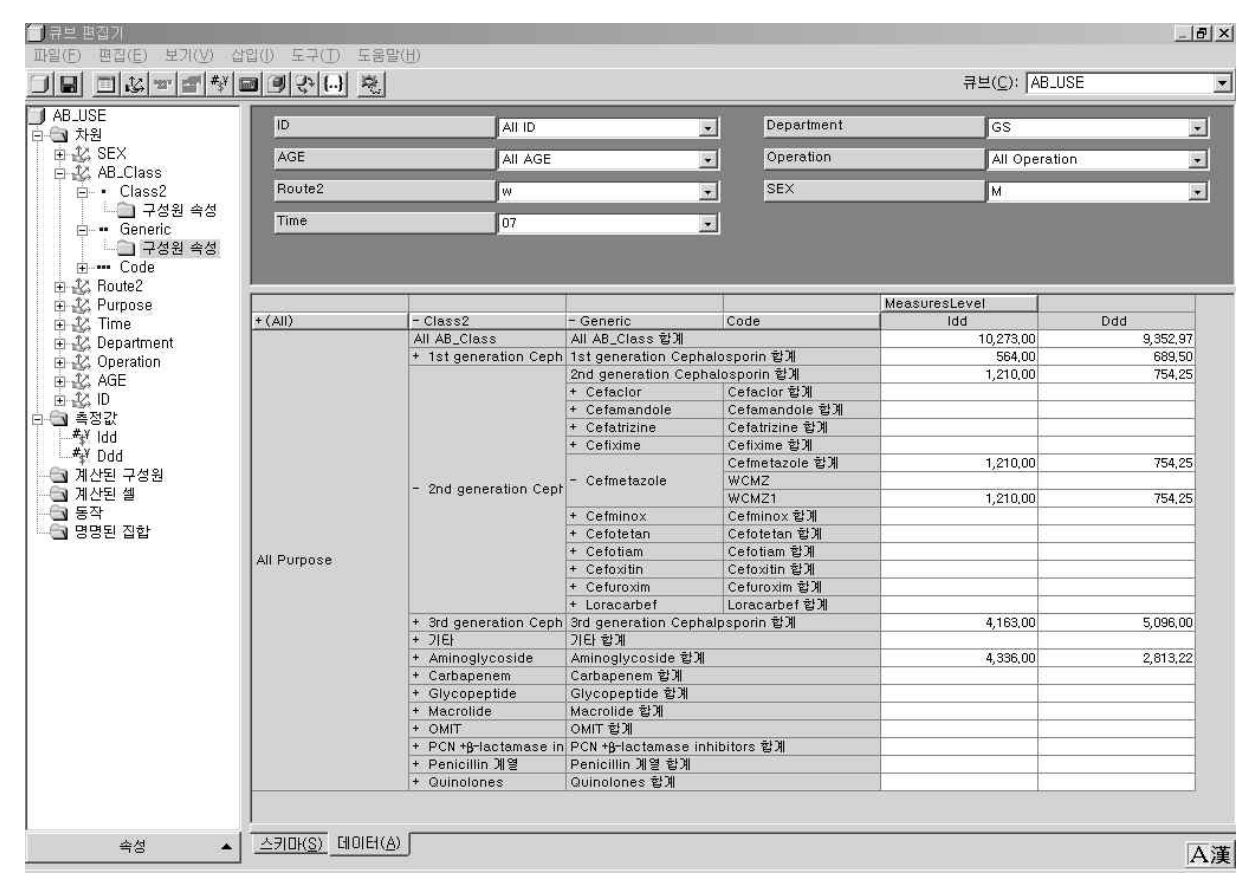

Fig. 7. Example 1 of OLAP query on antibiotic usage. Parenteral antibiotics administered to male patients on July 1997.

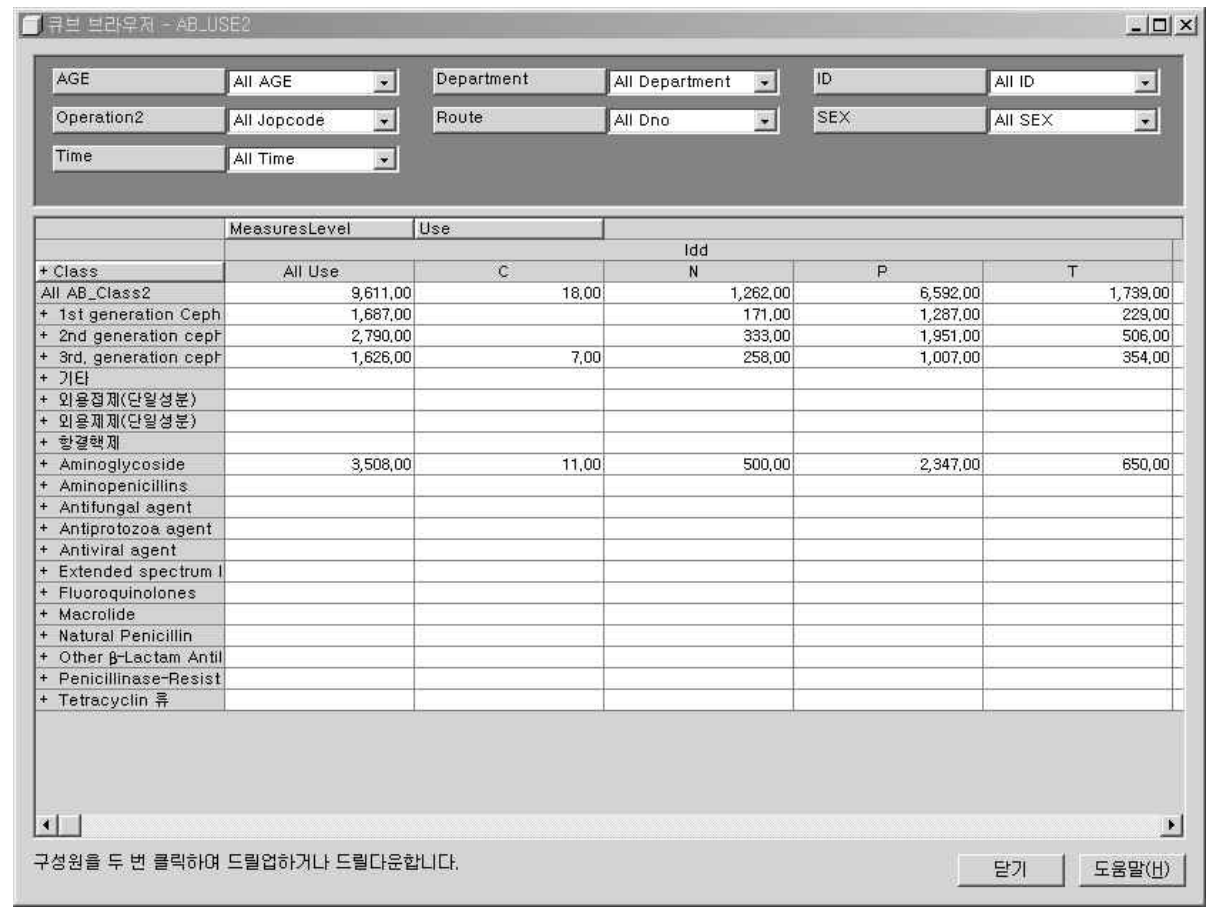

Fig. 8. Example 2 of OLAP query on antibiotic usage. The prophylactic versus therapeutic ratio of cephalosporin antibiotics was $3.9: 1$ (4,245 days : 1,089 days).
에 따른 결과라고 볼 수 있다. CARP 시스템도 데이터웨어하우스의 활용이 주목받던 이 시기에 구축되었으며, 데이터웨어하우스의 특 징인 통계량 산출 및 활용의 자동화 구현을 통한 항생제 내성 관리 가 목적이었다. 감염 분야에서 통계량 집계와 보고의 자동화 수립 에는 이전에도 개별적인 노력이 있었지만[19-22], 데이터웨어하 우스는 데이터 자동 전송 및 자동 보고 등의 기능을 포함하는 종합 적인 데이터 처리 자동화 시스템이다. 그러나 데이터웨어하우스는
기업 또는 기관의 업무 처리를 위한 기본 정보 시스템에 부가적인 기능으로 추가적인 하드웨어와 소프트웨어 비용이 소요되므로 주 로 대규모 프로젝트에서 활용되며 전사적인 활용을 목적으로 구축 되는 것이 보통이다. 따라서 감염관리에 특화된 개별적인 데이터웨 어하우스나 데이터마트 구축 사례는 많지는 않았으며 [5,23], 신종 플루, 메르스 등의 신종 감염병들이 유행하면서 최근에는 감염관리 에 대한 관심이 증가하고 있으며 감염 예측을 위해 데이터의 실시 
간 집계 및 처리를 위한 시스템 구축의 필요성이 높아지고 있다. 2011년 Chopra 등은 Detroit Medical Center 외래 환자에 대한 검사실과 약국 자료를 기반으로 하는 신종인플루엔자 A(H1N1) 감 시 방법을 평가하였고, 2012년 Zhao 등은 인플루엔자 유행 관찰을 위한 검사실 기반의 호흡기 바이러스 감시 시스템(Respiratory DataMart System) 경험을 보고하였다[24,25].

감염관리 데이터마트의 적용 예로 항생제 내성률, 환자 별 감염 정보, 혈액감염 관련 정보, 중심 정맥 카테터 사용 여부 파악, 항생 제 사용량, 그리고 감염 종류 및 항생제 내성과 항생제 사용의 연계 분석을 통한 질 관리 향상 및 감염 관련 비용 분석을 통한 적정 진료 의 수립 등을 들 수 있다. 데이터마트 구축을 통한 분석의 장점은 자 료 전송 및 통계량 산출을 구조화 및 자동화할 수 있어 주기적인 통 계치 산출 및 주문형 보고가 가능한 데 있다[5,23], 본 연구에서 항 생제 사용량에 대한 OLAP 구축을 시현하여 사용한 결과, 데이터베 이스로부터 집계를 위한 자료를 손쉽게 갱신할 수 있었으며, 하나 의 화면에서 다양한 분석을 할 수 있음을 알 수 있었다.

본 연구는 항생제 사용량에 대한 자료만을 OLAP 구축의 예로 살 펴보았으므로 항생제 내성 등의 자료와의 연관성 분석은 본 연구에 서 실시하지 못하여 추가 연구가 필요하다. 항생제 사용량 정보를 포함한 감염관리 데이터마트 구축 후의 다음 단계로는 구축된 정보 를 기반으로 임상 진료 시 직접적인 도움이 되는 시스템을 구축, 질 병 조사의 자동화, 각종 감염관련 보고를 자동화시키는 사업들이 될 것이며, 데이터 마이닝 기법을 이용하면 더 많은 감염관리에 대 한 숨은 지식의 발굴이 가능하고 이를 활용함으로써 진일보한 진료 의 질 향상에 기여하게 될 것으로 사료되었다.

\section{요 약}

병원정보시스템에 저장되어 있는 자료들은 적절성 평가 및 질 관리를 향상시키는 데 있어 많은 잠재력을 가지고 있으며 이를 기 반으로 하는 데이터웨어하우스의 구축은 질 관리의 향상과 임상진 료에 많은 도움을 줄 수 있는 것으로 알려져 있다. 본 연구는 감염관 리 정보의 체계적이고 효과적인 자료 분석을 위한 일환으로 항생제 사용량 분석이 가능한 데이터마트를 구축하였다. 감염관리의 구성 요소 및 평가 척도를 선정 후 XML DTD 방법으로 메타데이터를 설 계하였고 모델링을 통해 데이터마트를 구축하여 항생제 사용량 분 석을 위한 다차원 분석 도구인 OLAP를 시현하였다. 실험 자료는 1997년 7월 한 달 동안의 천안 지역의 일개 대학병원의 항생제 사 용량 자료를 이용하였다. 감염관리 메타데이터의 상위요소는 항생 제 내성 정보, 항생제 사용량 정보, 감염 정보, 검사 정보, 환자 정보 및 감염 관련 비용으로서 구성하였다. 이 중 항생제 사용량 정보를
스타 스키마에 적용하기 위한 데이터베이스의 설계를 하여 데이터 마트를 구축하였다. 그리고 일 개월 간 사용된 항생제 사용량에 대 해 OLAP을 시현하였다. 본 연구는 XML과 OLAP 기술의 구현을 통 해 항생제 사용량에 대한 감염관리 데이터마트를 수립하였다. 개념 적이고 구조화된 데이터마트의 구축은 감염관리 정보에 대해 신속 하고 다양한 분석을 제공할 것으로 사료되었다.
Acknowledgements: None
Funding: None
Conflict interest: None

\section{References}

1. Jarvis W. Selected aspects of the socioeconomic impact of nosocomial infections: morbidity, mortality, cost, and prevention, Infect Control Hosp Epidemiol. 1996;17:552-557.

2. Daikos GL, Cleary T, Rodriguez A, Fischl MA. Multidrug-resistant tuberculous meningitis in patients with AIDS. Int J Tuberc Lung Dis. 2003; 7:394-398.

3. Kim D, Kim N, Lee S. Technique and analysis of antibiotics use in national insurance claim data: Focused on antibiotics without DDD of WHO. Kor J Clin Pharm. 2007;17:19-32.

4. Rheem I, Choi DG, Park WS, Choi EK, Pai H. Individual drug day (IDD) as a measure of antibiotic usage in a university hospital: A new approach. J Korean Soc Chemother. 1998;16:51-60.

5. Wisniewski MF, Kieszkowski P, Zagorski BM, Trick WE, Sommers M, Weinstein RA. Development of a clinical data warehouse for hospital infection control. J Am Med Inform Assoc. 2003;10:454-462.

6. Garner JS, Jarvis WR, Emori TG, Horan TC, Hughes JM. CDC definitions for nosocomial infections. Am J Infect Control. 1988;16:128-140.

7. Chopra I, Hodgson J, Metcalf B, Poste G. New approaches to the control of infections caused by antibiotic-resistant bacteria. An industry perspective. JAMA. 1996;275:401-403.

8. Korean Society for Nosocomial Infection Control. Korean nosocomial infections surveillance manual 2006. 1st ed. Seoul: Gukjin; 2006.

9. Cho JH. Data Warehousing and OLAP. Seoul: Dae Chung; 1996.

10. Cho JH and Park SJ. The OLAP Technology. Seoul: Sigma Insight Com; 2003.

11. Haley RW, Culver DH, White JW, Morgan WM, Emori TG. The nationwide nosocomial infection rate. A new need for vital statistics. Am J Epidemiol. 1985;121:159-167, 182-205.

12. Weinstein RA. Nosocomial infection update. Emerg Infect Dis. 1998;4:416-420.

13. Kim JM. National survey on the current status of antibiotic use in Korea and a proposition on the appropriate use of antibiotics. J Korean Soc Chemother. 2001;19:105-195.

14. Pai H. Strategies for optimal antibiotics usage to control antimicrobial-resistant microorganisms in hospital. J Korean Soc Chemother. 1997;15:9-18. 
15. Kim SM, Lee NY, Chung JO. Prevalence and antimicrobial susceptibility against imipenem-resistant Acinetobacter baumannii and MRSA isolates from intensive care unit patients. Korean J Clin Lab Sci. 2001;33:65-73.

16. Chong MS, Lee K. Status of infection control in Jeju-area general hospitals. Korean J Clin Lab Sci. 2016;48:130-136.

17. Lee J, Lee S, Kim Y, Shin WG, Lee BK, Lee HJ. Drug use evaluation of vancomycin in pediatric patients (II) - The effect of approval for vancomycin use. J Korean Soc Qual Assur Health Care. 1994;1:32-43.

18. Kim SH, Choi HS, Kim HS, Shin WG, Shon IJ, Cho NC, et al. Drug use evaluation on ceftazidime. J Korean Soc Qual Assur Health Care. 1994;1:44-54.

19. Evans RS, Larsen RA, Burke JP, Gardner RM, Meier FA, Jacobson JA, et al. Computer surveillance of hospital-acquired infections and antibiotic use. JAMA. 1986;256:1007-1011.

20. Heininger A, Niemetz AH., Keim M, Fretschner R, Doering G, Unertl K. Implementation of an Interactive computer-assisted infection monitoring program at the bedside. Infect Control
Hosp Epidemiol. 1999;20:444-447.

21. Overhage JM, Suico J, McDonald CJ. Electronic laboratory reporting: barriers, solutions and findings. J Public Health Manag Pract. 2001;7:60-66.

22. Panackal AA, M'Ikanatha NM, Tsui FC, McMahon J, Wagner MM, Dixon BW, et al. Automatic electronic laboratory-based reporting of notifiable infectious diseases at a large health system. Emerg Infect Dis. 2002;8:685-691.

23. Trick WE. Building a data warehouse for infection control. Am J Infect Control. 2008;36:S75-81.

24. Chopra T, Binienda J, Mohammed M, Shyamraj R, Long P, BachD, et al. A practical method for surveillance of novel H1N1 influenza using automated hospital data. Infect Control Hosp Epidemiol. 2011;32:700-702.

25. Zhao H, Green H, Lackenby A, Donati M, Ellis J, Thompson C, et al. A new laboratory-based surveillance system (Respiratory DataMart System) for influenza and other respiratory viruses in England: results and experience from 2009 to 2012. Euro Surveill. 2014;19(3):pii=20680. 